\title{
Ayurveda perspective of Genetics w.s.r. to Bija, Bijabhaga and Bijabhagavayava
}

\author{
Available online at www.jijistweb.com
}

REVIEW ARTICLE

\section{Avinash Babanrao Chavan*}

H.O.D. and Associate Professor, Rachana Sharir Department, S.G.R Ayurved College, Solapur, India.

*Corresponding Author's E-mail: cavinash23@gmail.com

\begin{abstract}
Ayurveda is science of medicine practicing in India from thousands of years; the literature of ayurveda encompasses description of genetics. Sushruta has classified hereditary and congenital types of diseases such as; sthaulya, klaibya, prameha and other diseases occurs due to the defect in genetic component. Ayurveda also emphasized that the variation in prakriti is also due to the variation in genetic component. Therefore as per ayurveda the terms hereditary play vital role towards the health and well-being of an individual. Beeja (chromosome), beejabhaga (genes) and beejabhagavayava (fraction of part of chromosome) are important terms described by ayurveda to explain defects in sperm and ovum. The beeja, beejabhaga and beejabhagavayava are considered responsible for hereditary diseases along with other factors. Present article describe ayurveda perspective of genetics with special description of Beejabhaga and Beejabhagavayava.
\end{abstract}

Keywords: Beejabhaga, Beejabhagavayava, Genetics, Hereditary.

\section{INTRODUCTION}

Ayurveda describe concepts of genetics as qualitative and quantitative predominance of doshika from birth which is responsible for the specific prakriti of an individual. The predominance of doshika depends upon characteristics of shukra and shonita which unite during the process of sexual intercourse resulting child birth. The hereditary diseases are caused by abnormalities in shukra and shonita. Concept of beejabhaga also mentioned in Ayurveda which involve diseases due to the defect in ovum such as; yonivyapd. The damage of ovum gene (beejabhaga) leads sterile progeny while damage in part of this gene (beejabhagavayava) causes putipraja (dead foetus). Maternal defects may lead suchimukhi yonivyapat. The diseases such as kustha, arsha, prameha and yakshma may also consider hereditary disorders which may occur due to the shukra and shonita defects.

\section{Chromosomal Abnormality:}

The rare chromosomal disorders are samskarvahi, vakri, irsyabhirati and vatikshanda. The other chromosomal disorders are as follows:
Individual possess both testicular and ovarian tissue.

\section{Pavanendriya}

Unexplained involuntary infertility and azoospermia.

\section{Narashanda}

Male psedohermaphroditism, Narishanda female karyotype but the external genitalia resemble those of a normal male.

The factors which contribute towards the prevalence of genetic disorders are as follows:

- Defect in shukra and shonita.

- Bija, Bijabhaga and Bijabhagavayava

- Kala of conception and condition of uterus.

- Diatec regimen of the mother during pregnancy.

- Presence of diseases condition in parents.

- Characteristics of mahabhutas which comprising foetus, etc.

Bija, Bijabhaga and Bijabhagavayava: 
Ayurveda described three components as main genetic unit; Beeja, Beejbhaga and Beejbhagavyava. The smallest unit of Shukra \& Shonita considered as Beeja (sperm and ovum). The Beejbhaga (chromosomes) is component of Beeja which is responsible for development of body organs and tissues. It also transfers genetic information from one generation to other generation. Beejbhagavayava (gene) is subtle stage of beejbhaga which carry hereditary characters and responsible for particular manifestation in an individual. Sperm and ovum (Beejabhaga) are considered responsible for formation of organ. The vitiation in beejabhaga may results defective organ or defective progeny. As per modern science genetic polymorphism may be due to the difference in DNA sequence among individuals which describe specific characteristics of person differing from others.

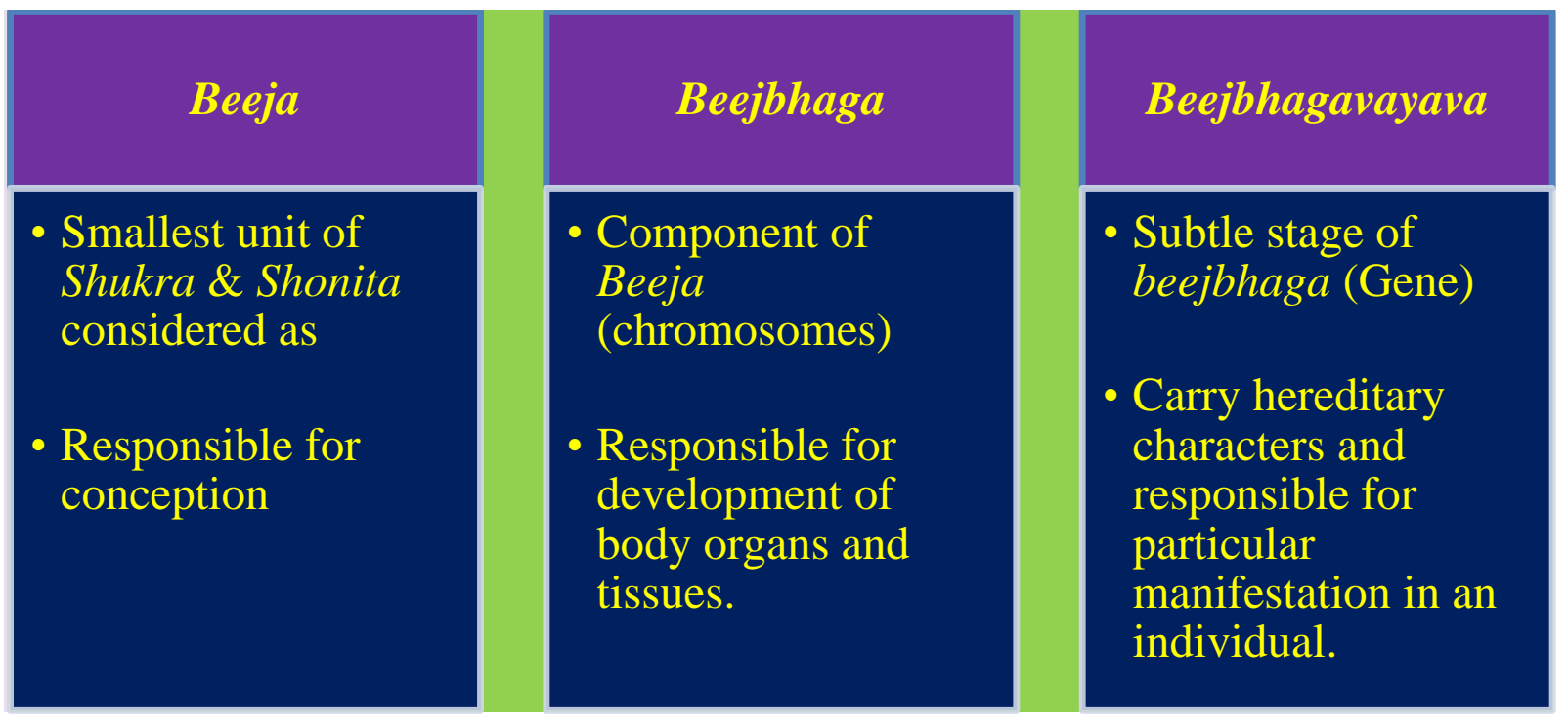

Figure 1: Genetic unites and their functions.

The birth of twins depends on the manner by which vayu divides the Bija, the separation of beeja by vayu if having predominance of shukra along with artava then male child will be born along with female child. Defected Beeja and Beejbhaga are responsible for the formation of defective body organ. Disease such as kushtha may impart in bijabhagavayava and hence may cause same offspring illness. Defect in bija, bijabhaga and bijabhagavayava may lead defect in child depending on gender. The birth of a bandhya female child occur when beejbhag in ovum is vitiated excessively which is responsible for the development of garbhashaya, when the part of beej which is responsible for the sperm production in foetus if vitiated excessively then the birth of a sterile male child may occur. Vitiation of beejbhagavayav may lead birth to a putipraja while similar case in sperm may gives birth to Putipraj.

\section{Bijabhaga and Bijabhagavayava towards demographic and ethnic variations}

Ayurveda text also described demographic and ethnic variations amongst society may be due to the different prakriti associated with the hereditary transformation from one generation to another. This specific hereditary transformation may be responsible for specific prakriti of cast (Jati Prasakta), specific prakriti of race (Kula Prasakta) and specific prakriti of locality (Deshanupatini). The chromosomal transformation play vital role towards the distinguish characteristics of one population from other one. In ayurveda Beejbhagavayava contributes towards this factor. 
Table 1: Charaka mentioned contribution of Bijabhaga and Bijabhagavayava towards specific characters of fetus:

\begin{tabular}{|c|c|c|}
\hline 1 & Characters linked to specific race & Jatiprasakta \\
\hline 2 & Familial characters & Kulaprasakta \\
\hline 3 & Geographical characters & Deshanupatini \\
\hline 4 & $\begin{array}{r}\text { Seasonal variations at the time of } \\
\text { conception }\end{array}$ & Kalanupatini \\
\hline 5 & Age dependent characters & Vayanupatini \\
\hline
\end{tabular}

\section{Genesis towards Prakriti}

The inherited characters of foetus may be associated with various originated factors such as;

* Characters associated with father (Pitrija).

* Characters associated with mother (Maatrija).

* Characters associated with soul (Atmaja).

* Characters associated with mind (Satvaja).

* Characters associated with diet (Rasaja).

* Characters associated with homologation (Satmyaja).

These all factors are responsible for the characters of individuals and nature of Bija, Bijabhaga and Bijabhagavayava contributes significantly towards these factors. Bija, Bijabhaga and Bijabhagavayava transform characters from father and mother to fetus and contributes towards Shukrashonita Prakriti, characters from season and uterine environment responsible for Kalgarbhashaya Prakriti, characters related to diet and lifestyle of pregnant mother resulted Maturahara Vihara Prakriti and attributes of Mahaabhuta towards Prakriti termed as Pancha Mahabhuta Vikara Prakriti. All these factors affect Prakriti of an individual at genetic level. Inherited characters from parents given more importance by Vagbhata and Sushruta, Charaka and Kashyapa emphasized on environmental factors towards Prakriti contribution. Nagarjuna consider environmental factors related to Prakriti of new born. Kashyapa had given importance to diet of pregnant mother towards the Prakriti of fetus.
The authors would like to thank IJDRA Journal for publishing my Article.

\section{CONFLICTS OF INTEREST}

The author declares that there are no conflicts of interest.

\section{REFERENCES}

1. Sushruta. Garbhavyakarna shariram. In: Sharma PV(editor). Sushruta samhita(with English translation of text and Danhana's commentary along with critical notes) Vol II.Varanasi: Chaukhambha Visvabharti; 2004. p. 162.

2. Tripathi NS. Concepts of formation of prakriti in Ayurveda.Indian journal of research Anvikshiki. 2011 may: 5: 1-5.

3. Ghodke Y, Joshi K, Patwardhan B. Traditional Medicine to Modern Pharmacogenomics: ayurveda Prakriti Type and CYP2C19 Gene Polymorphism Associated with the Metabolic Variability. Evid Based Complement Alternat Med. 2009.

4. Agnivesha, Charaka Samhita, Ayurveda-Dipika commentary by Chakrapanidutta, revised ed., Sutra Sthana (6:15-18), pg. 256, Chaukhambha Surbharati Prakashan, Varanasi (2011).

5. Kashyapa, Kashyapa Samhita, Vidyotini Hindi Commentary, Reprint, Sutra Sthana (18:11), pg. 2, Chaukhambha Surbharati Prakashan, Varanasi (2010).

6. Mitali Mukerji, Bhavana Prasher. Ayurgenomics: a new approach in personalized and Preventive medicine. Science and Culture, Jan-Feb 2011; 77(12): $10-17$.

7. Acharya YT. Charaka Samhita by Agnivesha. 4th ed. Varanasi: Chowkhambha Sanskrit Sansthan; 1997. p. 322.

8. Agnivesha, Charaka Samhita, Ayurveda-Dipika commentary by Chakrapanidutta, revised ed., Sutra Sthana (30:26), pg. 187, Chaukhambha Surbharati Prakashan, Varanasi (2011).

9. Sushruta, Sushruta Samhita, Nibandha Samgraha commentary by Dalhana, 7th ed., Sharira Sthana ( 2:5-6), pg. 345, Chaukhambha Orientalia, Varanasi (2012).

10. Agnivesha, Charaka Samhita, Ayurveda-Dipika commentary by Chakrapanidutta, revised ed., Chikitsa Sthana (30:9-36), pg. 634-636, Chaukhambha Surbharati Prakashan, Varanasi (2011). 